\title{
I disegni di viaggio di Étienne Gravier. Restituzioni prospettiche e ipotesi ricostruttive
}

\author{
Laura Aiello
}

Abstract

II presente contributo si muove nell'ambito dello studio delle tecnologie di rilievo e dei relativi codici della rappresentazione adottati alla fine del XVII secolo in ambito militare esplorativo.

In particolare l'attenzione è stata focalizzata su due manoscritti di Étienne Gravier, che tra il 1685 ed il I 687 intraprende, alle dipendenze di Luigi XIV, un viaggio esplorativo lungo le coste del Mediterraneo "a la faveur de la visitte des Eschelles du Levant, [...] avec les proiets pour y faire descente et s'en rendre maistres" [Gravier I687a, p. I r; Gravier 1687b, p Ir].

I documenti, digitalizzati dalla Biblioteca Nazionale di Francia, non sembrano avere recensioni dedicate ma sono resi disponibili per la consultazione dei testi e delle tavole di corredo.

L'analisi di queste ultime delinea la figura di un abile vedutista capace di servirsi di adeguati strumenti di misura per il calcolo degli angoli azimutali e quindi per la rielaborazione di carte nautiche e accurate viste dal mare.

Lo studio dettagliato della vista della città di Acco (San Giovanni D'Acri) ha permesso, attraverso i principi della restituzione prospettica, di rintracciare il punto di vista adottato nel panorama dal Gravier arrivando ad evidenziare una stretta corrispondenza tra questo e l'attuale pianta della città. II tracciamento degli angoli azimutali dimostra una forte relazione tra l'individuazione delle emergenze architettoniche e l'elaborato esaminato offrendo quindi una nuova fonte documentaria da interrogare per lo studio del sito.

Parole chiave

disegni di viaggio, città portuali, Acco, Étienne Gravier, restituzione prospettica.

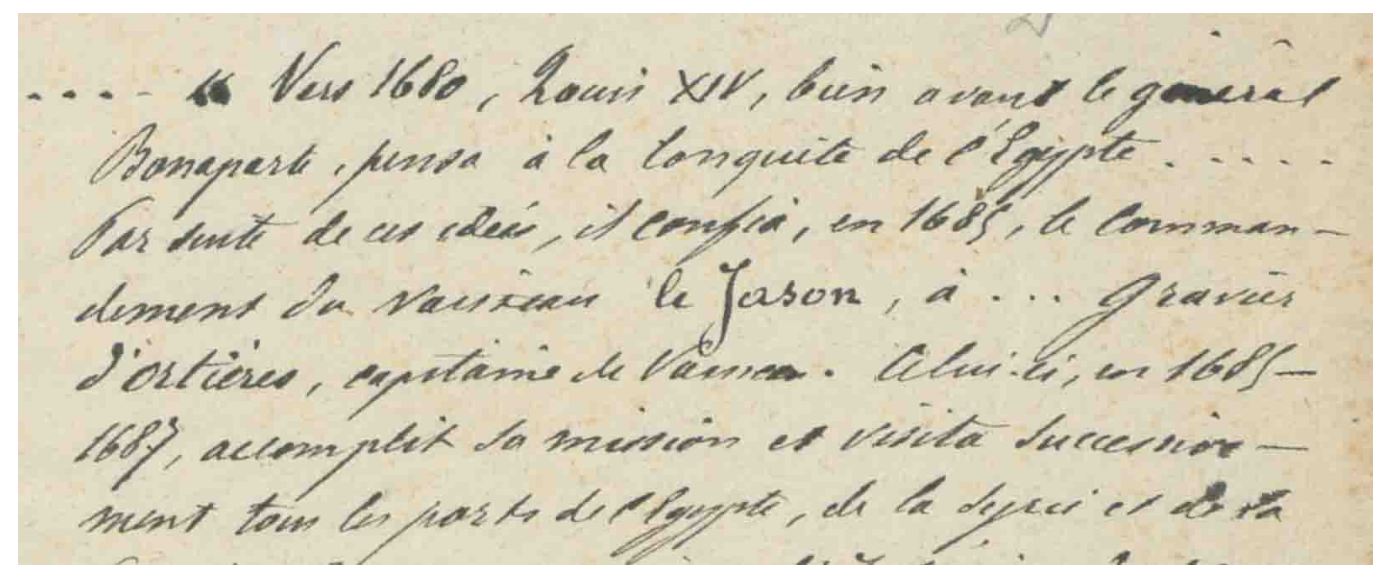


I disegni di viaggio come l'omonima letteratura, rappresentano un linguaggio narrativo che mira a illustrare persone, eventi e luoghi che l'autore si trova a visitare. Non si tratta necessariamente di un resoconto di ciò che prova l'autore-viaggiatore alla vista di nuovi territori o all'incontro con nuove culture, è possibile ad esempio distinguere una certa oggettività nei resoconti di viaggio settecenteschi, epoca razionale, cosmopolita e antropocentrica, e una maggiore emotività e soggettività del viaggiatore nel periodo del romanticismo e dei moti dell'animo.

Risulta evidente che tali rappresentazioni acquistano maggior valore se la loro committenza è finalizzata ad acquisire informazioni strategiche per progettare azioni belliche di tipo offensivo. La natura di tali rappresentazioni presuppone infatti la necessità di un approccio grafico dettato da un rigore geometrico capace di sfruttare le più moderne tecniche di rappresentazione disponibili al momento.

La spiccata connotazione documentaria quindi annovera tali opere fra le fonti storiografiche che come tali possono essere interrogate e analizzate per aggiungere un tassello in più alla ricostruzione storica degli eventi.

In tale sede l'interesse della presente trattazione si focalizza su alcune rappresentazioni realizzate nella seconda metà del XVII secolo commissionate da Luigi XIV, intento in quegli anni a progettare la conquista dell'Egitto.

Le immagini sono tratte da due distinti manoscritti, tra loro complementari, conservati presso la Biblioteca Nazionale di Francia, realizzati tra il I 685 e il 1687 da Étienne Gravier e contenenti le "tavole descrittive dello stato dei luoghi che i principi maomettani possedevano sulle coste del mar Mediterraneo" [Gravier I687a, p. Ir; Gravier I687b, p. Ir].

L'uso del medesimo titolo e i contenuti differenti lasciano pensare a un'opera in più volumi. Precisiamo che il primo manoscritto [Gravier 1687a] riporta la dicitura 'Tome l' solamente a matita, mentre il secondo esemplare [Gravier 1687b] riporta la dicitura Tôme troisieme trascritto a penna e con la medesima calligrafia dell'intero tomo. Ciò apre dei dubbi sulla possibilità che quello identificato come tomo uno possa essere la stesura di un'ulteriore 'edizione' e che il tomo tre sia l'ultimo esemplare di una stesura coordinata più ampia.

A conferma di ciò sembra convergere una nota manoscritta a firma di Gabriel Marcel, sul secondo volume, il Tôme troisieme, che in data 1872 specifica che sfortunatamente di questa raccolta sembra esserci pervenuto solo il terzo tomo.

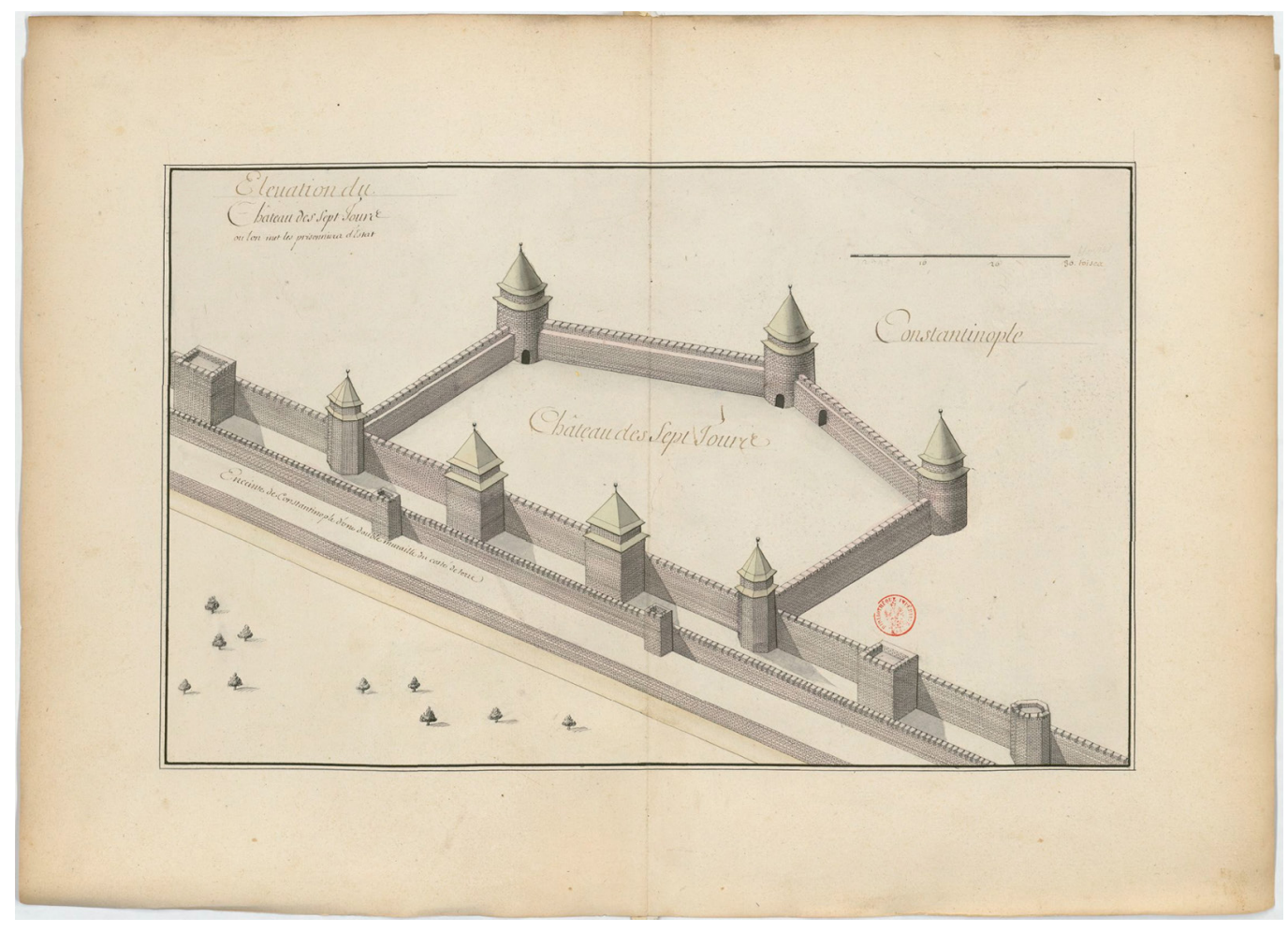


Dall'analisi dei luoghi recensiti, possiamo comunque affermare che, vista la complementarità del contenuto dei due manoscritti, è plausibile pensare alla perdita di un ulteriore volume che potesse descrivere i porti della moderna Turchia meridionale.

L'indice delle rappresentazioni del primo manoscritto riporta infatti 54 tavole divise nelle seguenti sezioni: Costantinople, Andrinople, Smirne, Solonique, Athene, Candie. Le sei località rappresentano la mappa dei porti strategici dell'arcipelago Egeo e del passaggio verso il mar Nero. L'indice delle rappresentazioni del secondo manoscritto riporta 5 I tavole divise nelle seguenti sezioni: l'Isle de Chipre, la Sirie, la Terre Saincte e l'Egipte. In particolare quest'ultimo indice appare incompleto per quanto attiene 7 tavole della sezione dedicata alla parte meridionale della Terra Santa (tav. 24-30).

L'indice riporta solo la numerazione delle tavole senza il titolo e non esistono le tavole associate. Invece sono state aggiunte a matita da un secondo redattore la tavola 19 bis, nella sezione Terrasanta, e altre tre tavole finali (tavv. 49-5I) nella sezione dedicata all'Egitto. Possiamo ipotizzare in tal caso un rimaneggiamento d'archivio che abbia in qualche modo cercato di riorganizzare il fondo documentario.

I disegni permettono di effettuare alcune osservazioni sull'uso delle conoscenze geometriche adottate da quello che viene definito capitaine de vaisseau ossia: Étienne Gravier, marquis d'Ortières. La raccolta annovera carte nautiche con l'annotazione di alcune misurazioni, rappresentazioni in pianta ed elevato di edifici di grande valore architettonico, sviluppi in proiezione parallela ben costruiti e dotati di una scala grafica di riferimento (fig. I), fino ad includere delle viste in una prospettiva scenografica (fig. 2) non così rigorosa come quella che oggi realizziamo tramite il metodo della Proiezione Centrale. Tra i disegni di miglior pregio possiamo segnalare le viste panoramiche realizzate con una perizia di dettaglio notevole.

Avendo approntato tali studi per un particolare interesse verso le città portuali della Terra Santa [l], è apparsa di particolare interesse la vista panoramica di Acco ripresa dal mare (fig. 3). Un'indagine approfondita ha permesso di rintracciare, tramite i principi della restituzione prospettica, l'esistenza di un punto di vista preciso (figg. 4, 5).

L'ipotesi avanzata sembra dimostrare una precisa corrispondenza tra la vista panoramica della città realizzata da Gravier e la mappatura delle emergenze architettoniche ad oggi note.

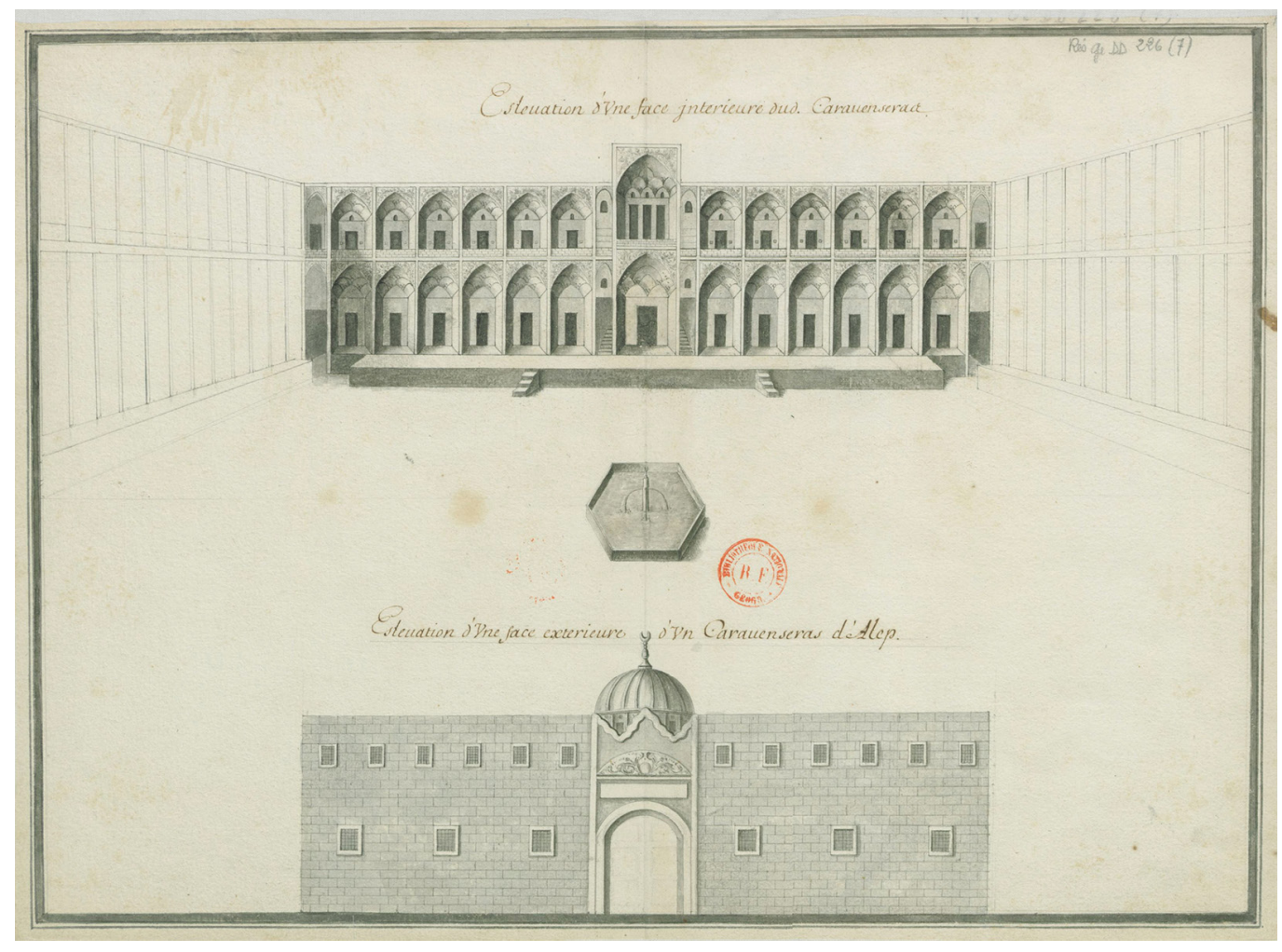


Per effettuare tale operazione sono stati necessari alcuni passaggi fondamentali di seguito enunciati. In prima istanza si è dovuto effettuare un accurato riconoscimento delle emergenze architettoniche rappresentate da Gravier in elevato, tale operazione è risultata agevolata da alcuni toponimi riportati in corrispondenza dei principali edifici. Si possono osservare due tipi di annotazioni, due segnate a china relative al palais du grand maitre e all'Eglise St. Jean, e una segnata a matita ma con la stessa calligrafia relativa a l'Eglise Saint André.

Purtroppo le attuali evidenze dei tre monumenti permettono di collocare soltanto il Palazzo del Gran Maestro oggi identificabile con la cittadella degli ospedalieri [Luschi, Aiello 2020]. $\mathrm{Da}$ un'accurata analisi della rappresentazione, alcune invarianti architettoniche sul fronte mare sembrano tuttavia trovare ancora una buona corrispondenza.

L'angolazione visuale, identificabile con un'inquadratura della città da sud, offre molti dettagli sulla condizione del porto. In primo piano ne sono infatti facilmente riconoscibili i resti, sul quale sembra insistere parte di quello moderno, mentre alcuni resti affioranti permettono di intuirne l'estensione completa. Di facile riconoscimento appare la moschea nei pressi del porto, inquadrata dalle imbarcazioni e la cui collocazione ricalca quella dell'attuale Sinan Basha. Procedendo verso destra un'imponente torre quadrangolare sulla linea di costa appare identificabile con l'attuale torre del burj al-Sultan. Tre arcate sembrano ricalcare il sito dell'ex convento delle clarisse su cui sorge l'attuale khan a-Shawarda. La panoramica si estende per un lungo tratto a mostrare i resti di numerose costruzioni in rovina. La geografia del luogo mostra sullo sfondo un secondo piano montuoso che implica il volgere dello sguardo verso l'entroterra. Sul primo piano appare all'estrema destra un promontorio rappresentante una piccola collinetta vicino alla costa che dalle analisi morfologiche può essere identificata con il Tell el-Fukhar la 'collina dei vasi d'argilla', sito archeologico localizzato ad oriente della città attuale.

Fissati i principali target di riferimento, e dopo averli identificati sulla moderna planimetria della città, il passo successivo è stato quello di ricostruire un impianto prospettico capace di ricreare una corrispondenza biunivoca tra la vista panoramica della città è la rispettiva pianta. Per realizzare tale operazione, l'ipotesi di partenza è stata quella di trovarsi al cospetto di una rappresentazione effettuata con i mezzi propri di un disegnatore di carte nautiche quindi dotato di strumenti capaci di effettuare misure angolari esatte.

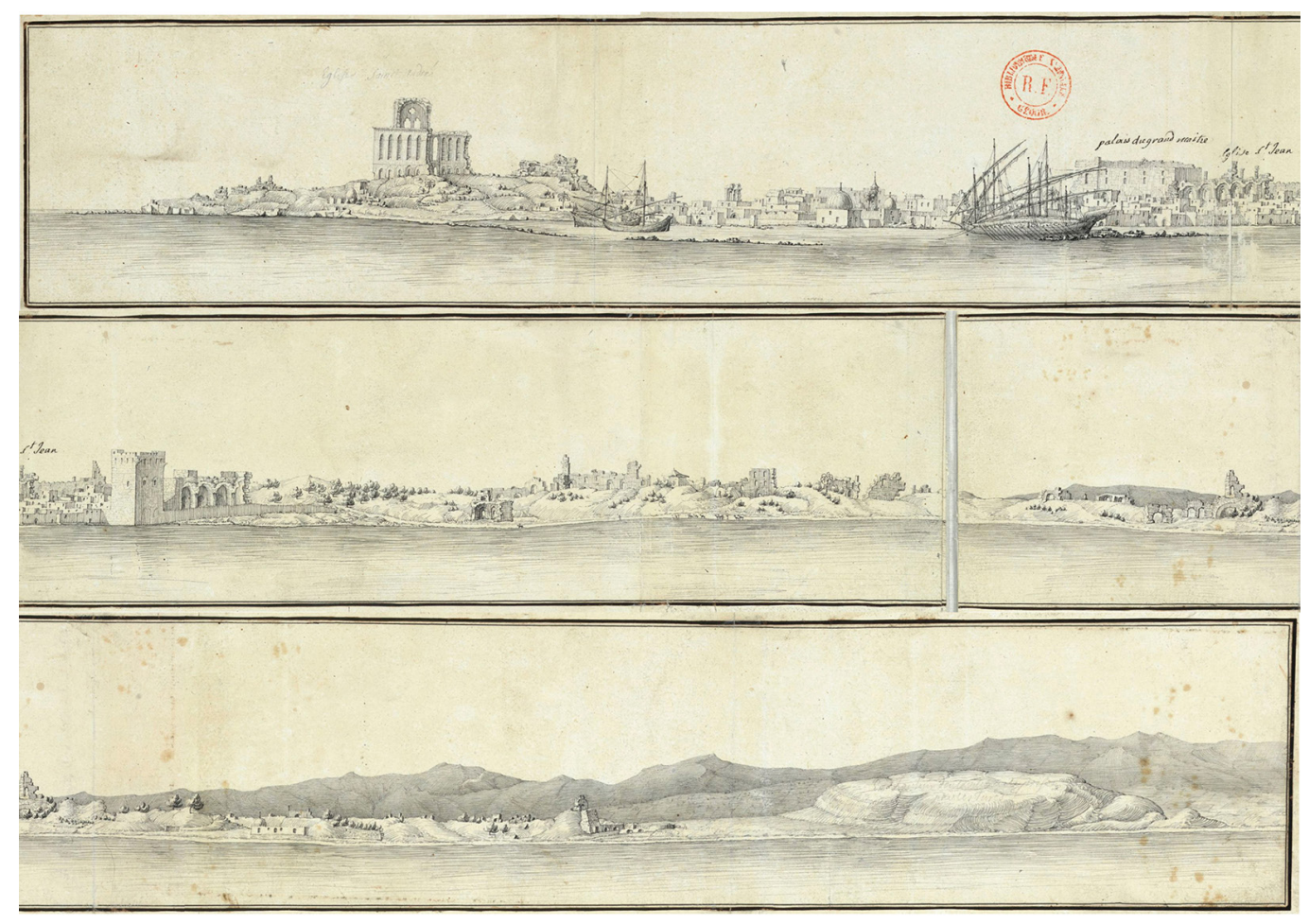


Fig. 4. Studi sul centro di proiezione prospettico del panorama di San
Giovanni d'Acri realizzat dal Gravier nel 1687 (elaborazione grafica Laura Aiello).

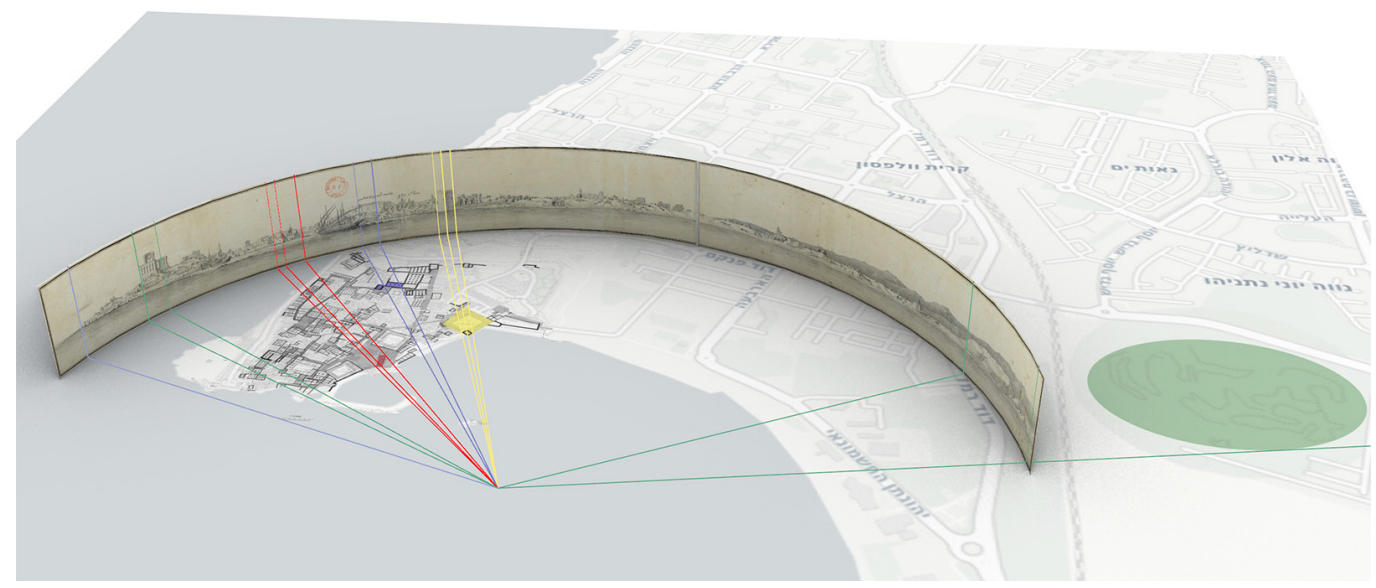

L'estensione orizzontale della vista ha implicato la necessità di ipotizzare, sul piano teorico, l'utilizzo di un quadro di riferimento curvo, assimilabile a una porzione di cilindro verticale, che permettesse quindi di non incorrere nella normale deformazione ottica che presuppone una proiezione da un punto proprio su un quadro piano.

È bene precisare che tale impostazione non rappresenta una costruzione geometrica dichiarata dal disegnatore (Gravier) ma viene adottata dallo scrivente come ausilio per individuare la risultante geometrica derivata dall'atto del disegnare i panorami utilizzando come strumento tecnico disponibile la misurazione degli angoli azimutali delle varie emergenze architettoniche. Ipotizzando infatti di impostare il punto di vista del disegnatore su un'imbarcazione ancorata poco fuori dal porto della città e di voler rappresentare il panorama in maniera fedele, non resterebbe al disegnatore che attribuire ad ogni angolo/intervallo azimutale rilevato un'estensione lineare del panorama rappresentando in maniera proporzionata tutti gli elementi compresi tra un intervallo e il successivo.

Tale prassi, anche se non espressamente codificata alla fine del 1600 sarà comunque assimilata e trattata in termini scientifici da Gaspard Monge (1746-818) nel suo trattato di geometria descrittiva [Corridi 1838]. Nel testo è infatti possibile leggere: "I panorama sono prospettive descritte sopra superficie cilindriche verticali a base circolare, essendo il punto di vista sull'asse delle superficie medesime. Per mettere un punto qualunque in prospettiva

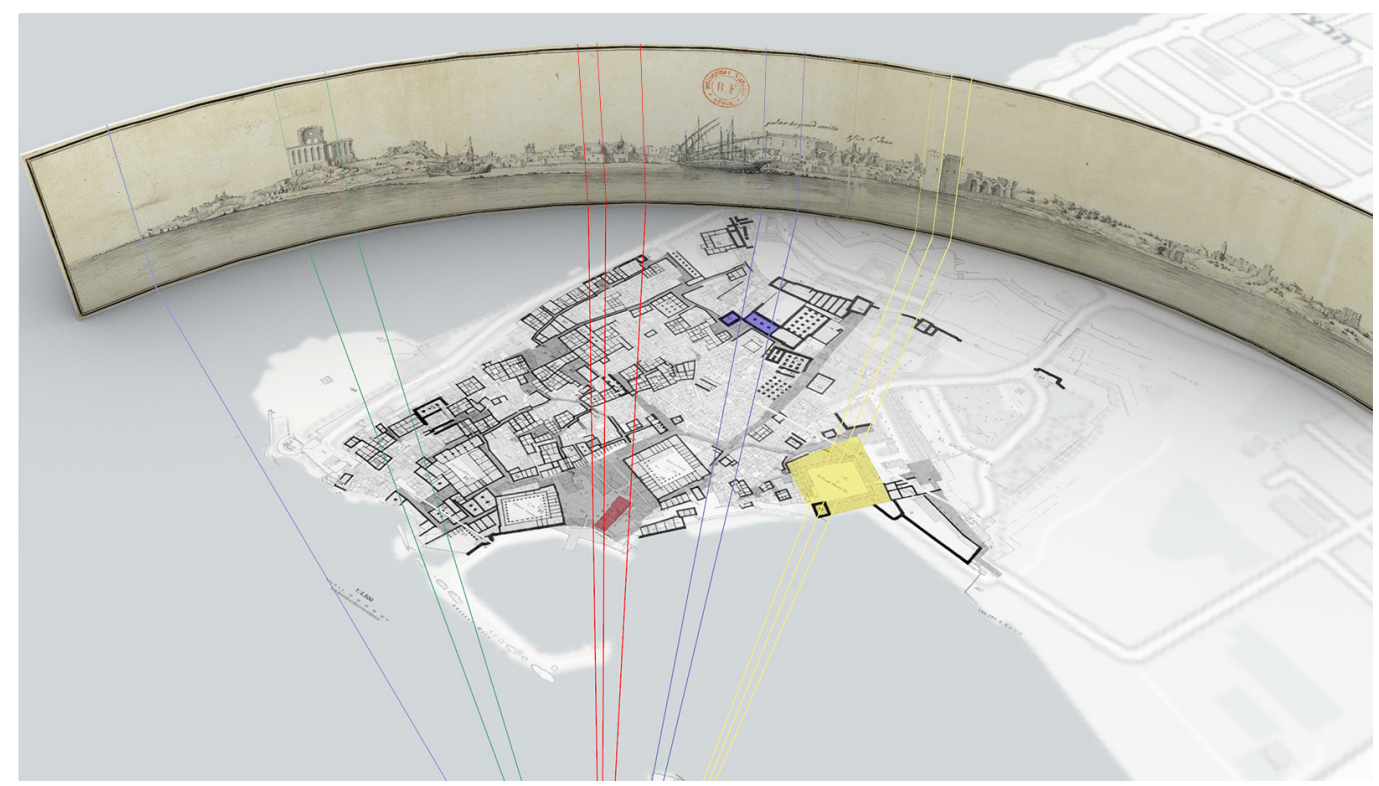




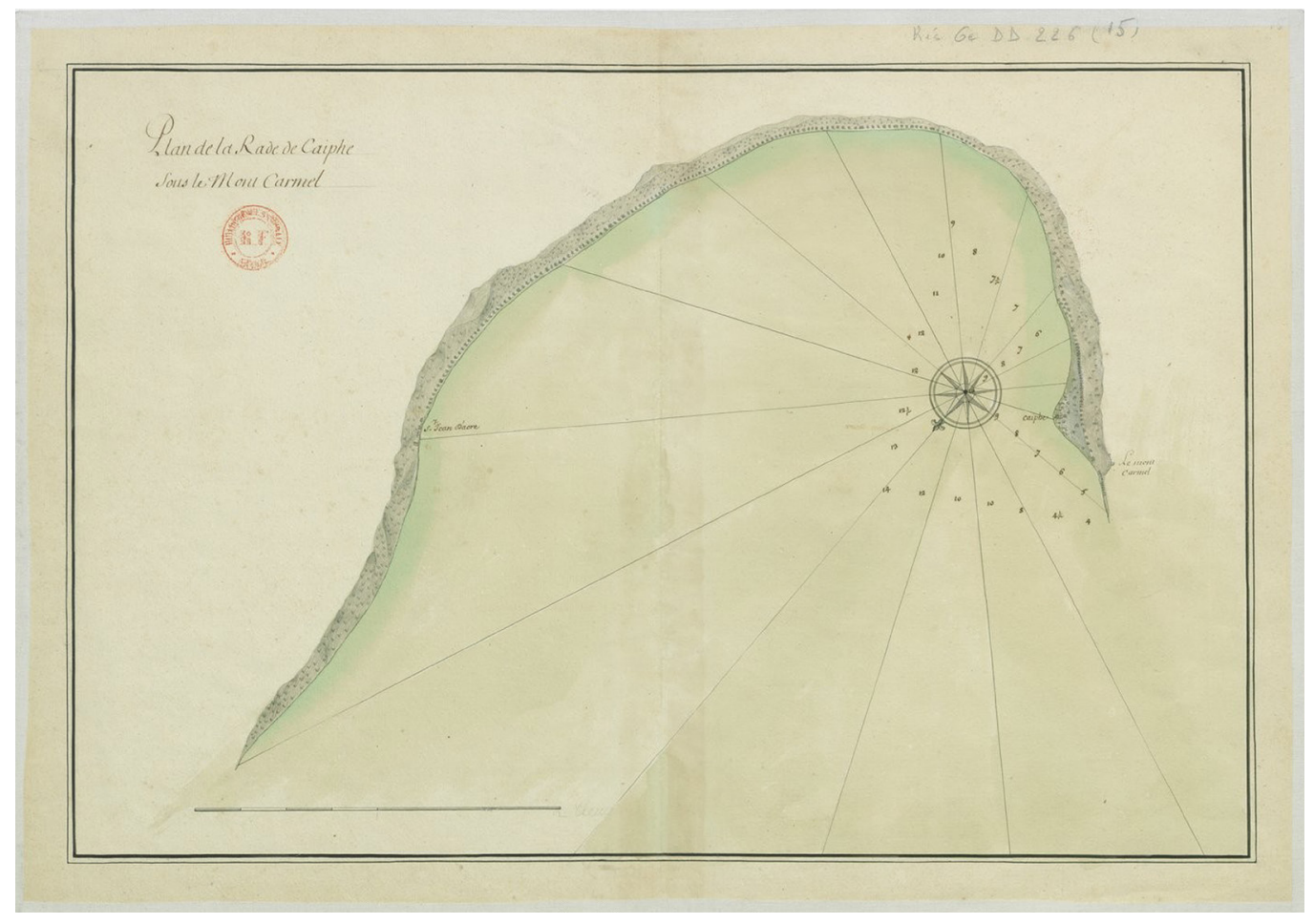

sulla superficie d'un cilindro verticale, immagineremo che pel punto proposto, e per l'occhio sia condotto un piano verticale, il quale taglierà tal superficie secondo una delle sue costole determinata dallincontro della traccia orizzontale del piano colla circonferenza del circolo che serve di base al cilindro. Facendo la projezione verticale di questa costola, il suo incontro colla projezione verticale del raggio visuale determinerà l'altezza a cui s'innalza l'intersezione di questo raggio colla superficie del cilindro al di sopra della base di esso; e mediante questi dati sarà facile di costruire la prospettiva del punto proposto, e sulla superficie del cilindro stesso, e sul quadro supposto sviluppato" [Corridi I838, pp. 193, 194].

II trattato descrive quindi in maniera scientifica le esatte procedure da attuare nella rappresentazione di un panorama riconoscendo la necessità di dover ipotizzare l'ausilio di un quadro cilindrico. A ulteriore supporto alla teoria sulla tecnica di rappresentazione appare interessante osservare la carta nautica, disegnata dallo stesso Gravier (fig. 6), del golfo di Caiphe, Haifa. La carta riporta al largo della costa di Haifa una rosa dei venti con i rispettivi raggi azimutali che suddividono la carta in settori secondo i punti cardinali. L'analisi del documento permette di apprezzare una tecnica grafica capace di mescolare una visualizzazione in pianta, data dalla silhouette linea di costa, e la rappresentazione di un lungo panorama.

Osservando da vicino la rappresentazione è infatti possibile apprezzare che ciò che sembra a prima vista la descrizione planimetrica dei territori costieri in realtà rappresenta una miniatura di tutto il panorama giungendo in tal modo ad offrire una descrizione più ampia anche dell'entroterra osservabile dal mare. In questo modo, prestando attenzione alla città di Haifa è possibile scorgere la rappresentazione del monte Carmelo e la presenza di alcuni edifici sulla sua sommità (fig. 7), al contempo osservando la città di Acco si può notare come anche in una miniatura così sommaria appare emergere un imponente edificio sul margine nord della città, probabilmente identificabile con le grandiose rovine del Sant'Andrea (fig. 8). Dalle analisi qui presentate, il riconoscimento in pianta del punto di visuale del panorama e l'associazione azimutale dei principali land marker danno accesso ad un nuovo banco di informazioni relativo al posizionamento dei principali monumenti storici ad oggi perduti aprendo nuove prospettive di ricerca a supporto dell'archeologia del sito. Evidenziamo in tale contesto come tali studi convergano verso attuali ricerche relative alla controversa collocazione del sito storico della chiesa di Sant'Andrea [Luschi 20 I8, pp. 27-38; Zerbini,Vezzi 20 I 8;Taormina 20 I9, pp. 75-90]. 
Fig. 7. Plan de la Raide

[Gravier 1687b, Table 15].
Dettaglio di Caiphe, Haifa.

Fig. 8. Plan de la Raide de Caiphe', I 685-1687

Gravier 1687b, Table

15]. Dettaglio di St. Jean D'Acre, Acco.
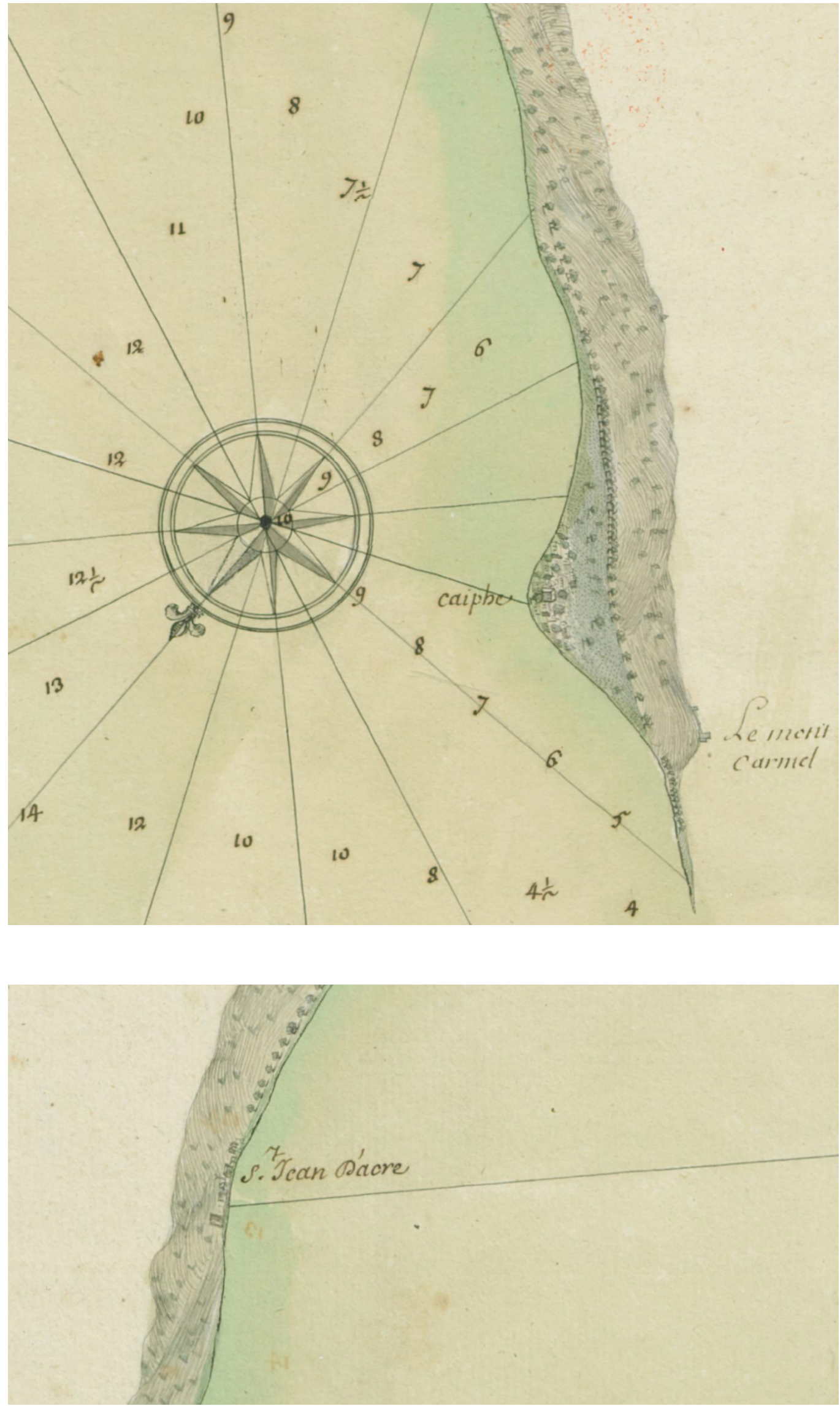
Fig. 9. Studi geometrici sulle costruzioni

prospettiche, 1640

[Desargues 1640, p. 5]

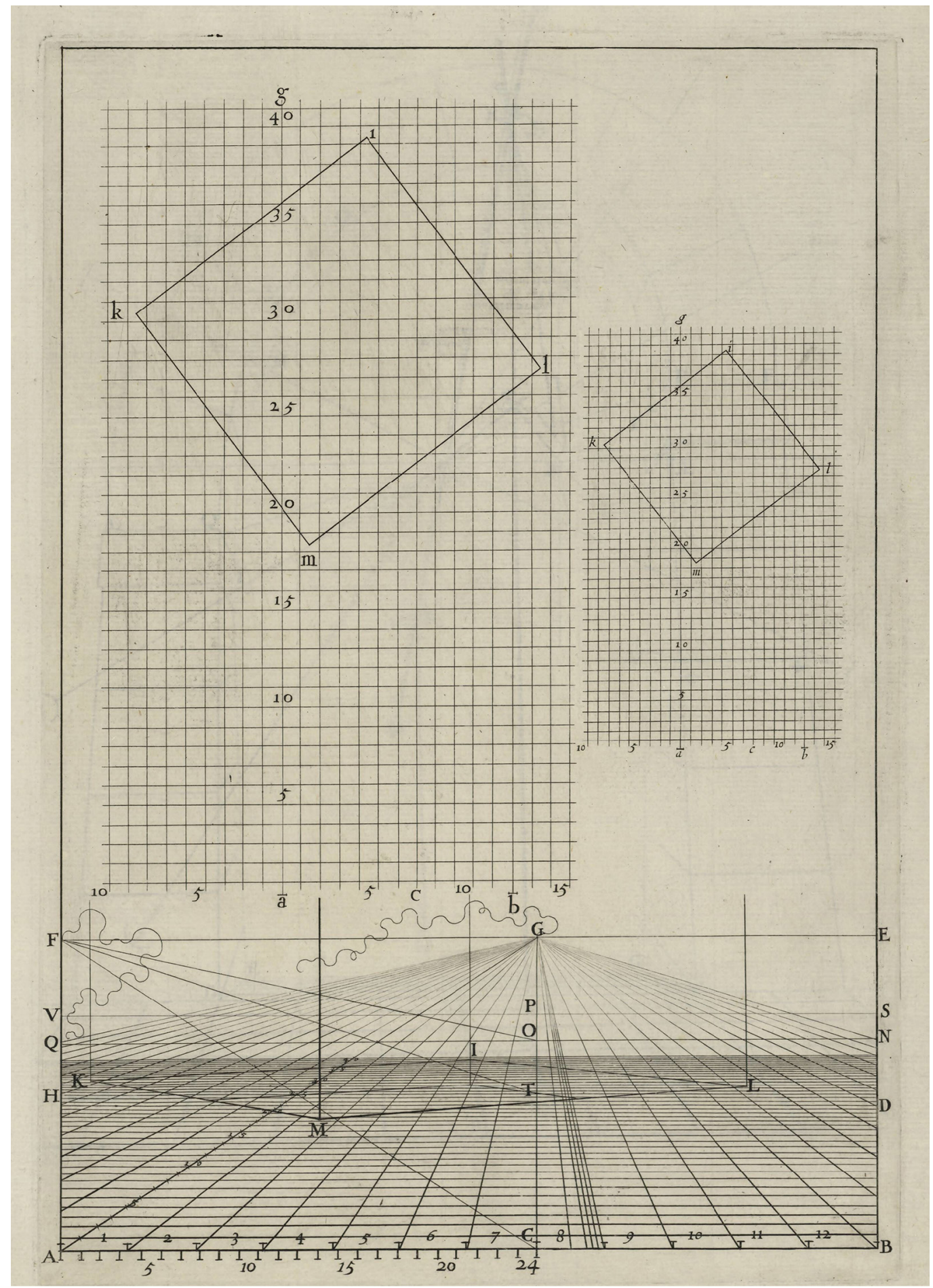

\section{Conclusioni}

Possiamo affermare dunque che l'analisi delle rappresentazioni grafiche di monsieur Gravier evidenziano un importante tassello nello studio dell'evoluzione delle tecniche di rappresentazione del XVII secolo soprattutto in ambito geografico e nella rappresentazione di paesaggi nel quale sembra eccellere.

La ricostruzione degli impianti prospettici permette di estrapolare importanti informazioni sull'esatta collocazione geografica dei monumenti perduti negli ultimi quattro secoli. Infor- 
mazioni che, se coordinate con puntuali indagini sui singoli monumenti, potrebbero infine offrire nuovi importanti spunti di ricerca nelle indagini archeologiche.

Restando in ambito tecnico, l'uso delle prospettive di cui Gravier si avvale per la rappresentazione degli edifici utilizza un impianto scenografico, ovvero a più punti di fuga. Utilizza quindi una prassi funzionale alla visualizzazione dell'oggetto distaccandosi dalle regole geometriche di prospettiva centrale.

Allargando lo sguardo al panorama teorico dell'epoca possiamo in tal caso osservare che la prassi non segue pedissequamente l'impostazione teorica dei trattatisti contemporanei. Ricordiamo infatti come già l'architetto Girard Desargues (I59|-|66|) nel suo breve trattato del taglio delle pietre [Desargues 1640] avesse discusso della "prospettiva di una figura ed il collocamento dei suoi piani geometrali" [Aterini, 2009, p. 39].

Non di meno potremmo argomentare che non è sempre dovuto da parte di uno specialista padroneggiare tutte le scienze della rappresentazione così da rendere Gravier meno interessante per i dettagli a piccola scala ma comunque meritevole di approfondimento per quanto concerne le rappresentazioni a grande scala il cui studio ha dimostrato di poter offrire una importante fonte documentaria da interrogare per lo studio dei siti storici del Mediterraneo orientale.

\section{Note}

[I] I presenti studi nascono e si sviluppano all'interno del programma di ricerca italo-israeliano Askgate con riconoscimento del Ministero degli Affari Esteri e della Cooperazione Internazionale.

\section{Riferimenti bibliografici}

Aterini B. (2009). Introduzione ai metodi della rappresentazione della Geometria Descrittiva. Firenze: Alinea.

Corridi F. (a cura di) (1 838). Trattato di Geometria descrittiva di G. Monge. Con l'aggiunta d'una teorica delle ombre e della Prospettiva estratta dalle lezioni inedite dell'autore per cura del signor Brisson. Firenze.

Desargues G. ( 640). Maniere universelle de S.G.D.L. touchant la pratique du trait à preudes pour la coupe des pierres an l'Architecture. Parigi.

Gravier É. (1687a). Estat des places que les princes mahométans possèdent sur les costes de la mer Méditerranée et dont les plans ont esté levez par ordre du Roy a la faveur de la visitte des Eschelles du Levant, que Sa Majesté a fait faire les années 1685 1686 et 1687 avec les proiets pour y faire descente et s'en rendre maistres. Tome I [Levés d'ordre du sieur Gravier d'Ortière commandant le vaisseau de Sa Majesté le Jason].

Gravier É. (1 687b). Estat des places que les princes mahométans possèdent sur les costes de la mer Méditerranée et dont les plans ont esté levez par ordre du Roy a la faveur de la visitte des Eschelles du Levant, que Sa Majesté a fait faire les années I 685 , I 686 et 1687 avec les proiets pour y faire descente et s'en rendre maistres. Tome Troisième [Levés d'ordre du sieur Gravier d'Ortière commandant le vaisseau de Sa Majesté le Jason].

Heather J.F. (Ed.) (I85 I). An Elementary treatise on Descriptive Geometry, whit a Theory of shadows and of perspective: extracted from the French of G. Monge. London: John Weale, 59, High Holborn.

Luschi C., Aiello L. (2020). La ricostruzione storica della città attraverso l'iconografia urbana. II caso studio di San Giovanni d'Acri. In Arena A. et al. (a cura di). Connettere. Un disegno per annodare e tessere. Atti del $42^{\circ}$ Convegno Internazionale dei Docenti delle Discipline della Rappresentazione/Connecting. Drawing for weaving relationships. Proceedings of the 42th International Conference of Representation Disciplines Teachers, pp. 2369-2382. Milano: FrancoAngeli.

Luschi C.M.R. (20।8). Among the archaeologists and the designers: a critical survey of Sant'Andrea of Acre in Israel - Wśród archeologów i projektantów: krytyczna ankieta kościoła Sant'Andrea Akko w Izraelu. In Czasopismo Techniczne, vol. I I.

Migliari R. (2009). Geometria descrittiva. Voll. I e II. Torino: CittàStudi Edizioni.

Taormina F. (2019) Akko e la sostenibilità morfologica della città antica. Saggio sulla vita delle forme. Palermo: 40due edizioni.

Zerbini M., Vezzi A. (2018). II nuovo orizzonte del porto crociato di San Giovanni d'Acri. In Benincasa F. (a cura di). Seventh International Symposium: monitoring of Mediterranean Coastal Areas: Problems and Measurement Techniques. Livorno (Italy), June 19-20-21, 2018, pp. 213-221. Firenze: Firenze University Press.

\section{Autore}

Laura Aiello, Università degli Studi di Firenze, laura.aiello@unifi.it

Per citare questo capitolo:Aiello Laura (202I).I disegni di viaggio di Étienne Gravier. Restituzioni prospettiche e ipotesi ricostruttive/Travel Drawings by Etienne Gravier. Perspective Restitution and Reconstructive Hypotheses. In Arena A. Arena M., Mediati D. Raffa P. (a cura di). Connettere Un disegno per annodare e tessere Linguagoi Distanze Tecnologie. Atti del $42^{\circ}$ Convegno Internazionale dei Docenti delle Discipline della Rappresentazionel Connecting Drowing for weaving relationship. Longuages Distances Technologies. Proceedings of the 42th International Conference of Representation Disciplines Teachers. Milano: FrancoAngeli, pp. 1884-1901. 


\title{
Travel Drawings by Étienne Gravier. Perspective Restitution and Reconstructive Hypotheses
}

\author{
Laura Aiello
}

Abstract

This paper belongs to the field of the study of survey technologies and related representation codes adopted at the end of the seventeenth century in the military exploratory field.

Especially attention is focusing on two manuscripts by Étienne Gravier, who between I685 and I687 undertook an exploratory journey along the coasts of the Mediterranean for Louis XIV, "a la faveur de la visitte des Eschelles du Levant, [...] avec les proiets pour y faire descente et s'en rendre maistres" [Gravier I687a, p. Ir; Gravier I687b, pI r].

The documents, digitized by the National Library of France, do not seem to have dedicated reviews but are made available for consultation of the texts and drawings.

The analysis of the drawings highlights the figure of a skilled landscape architect capable of using suitable measuring instruments for the calculation of azimuth angles and therefore, for the elaboration of nautical charts and detailed views from the sea.

The study of the panorama of the city of Acco (San Giovanni D'Acri) has allowed, through the principles of perspective restitution, to trace the point of view adopted by Gravier, coming to highlight a close correspondence between this and the current city plan. The tracking of azimuth angles demonstrates a strong relationship between the identification of architectural emergencies and the panorama examined. This correspondence, therefore, offers a new documentary source to be interrogated for the study of the site.

Keywords

travel drawings, port cities, Acco, Étienne Gravier, perspective restitution.

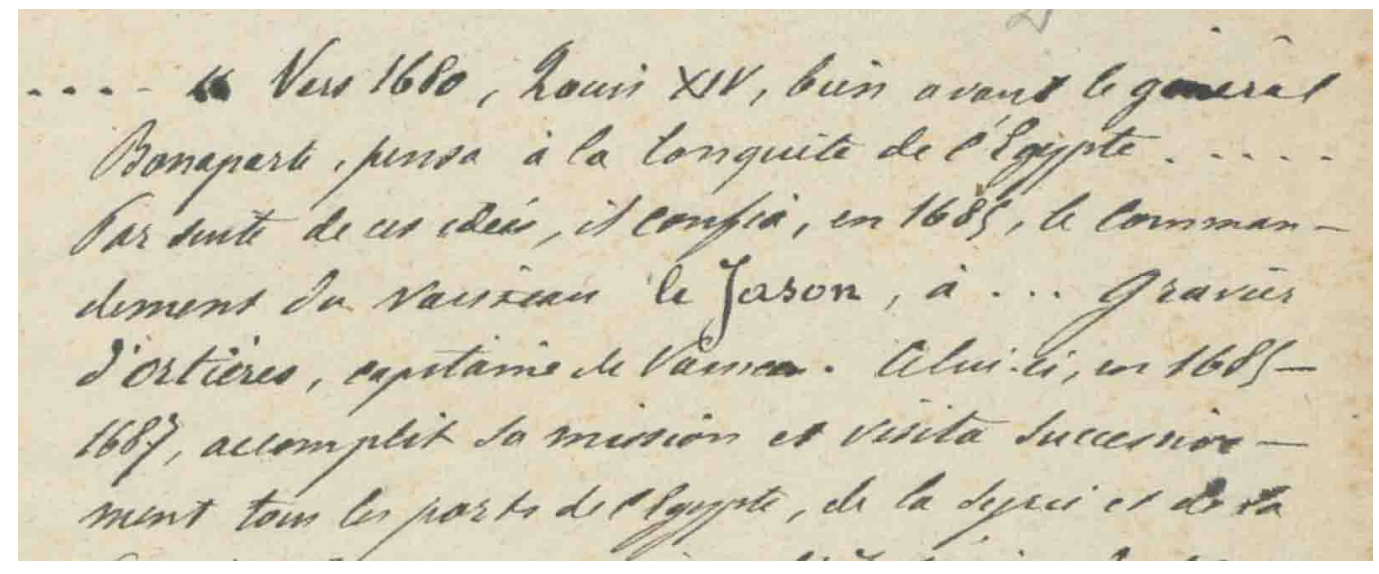


Travel drawings, like the literature of the same name, represent a narrative language that aims to illustrate people, events and places that the author is visiting. It is not necessarily a diary that narrates what the author-traveller feels at the sight of new territories or the encounter with new cultures. for example, it is possible to recognize the objectivity used in eighteenth-century travel reports, a rational, cosmopolitan and anthropocentric era, against a greater emotionality and subjectivity of the traveller in the period of romanticism and the motions of the soul. Such representations acquire greater value if their client is aimed at acquiring strategic information to plan offensive war actions. The nature of these representations presupposes the need for a graphic approach dictated by a geometric rigour capable of exploiting the most modern representation techniques available at that moment.

The marked documentary connotation, therefore, includes these works among the historiographical sources which as such can be interrogated and analyzed to add an extra piece to the historical reconstruction of the events.

In this context, the interest of this discussion focuses on some representations made in the second half of the seventeenth century commissioned by Louis XIV, at the time committed to planning the conquest of Egypt.

The images are taken from two distinct manuscripts, complementary to each other, preserved at the National Library of France, created between 1685 and 1687 by Étienne Gravier and containing the "descriptive tables of the state of the places that the Mohammedan princes owned on the coasts of the sea Mediterranean" [Gravier I687a, Ir; Gravier I687b, p. Ir]. The use of the same title and the different contents suggest a work in several volumes. We specify that the first manuscript [Gravier 1687a] bears the words 'Tome I' only in pencil, while the second one [Gravier 1687b] bears the words Tôme troisieme transcribed in ink and with the same handwriting of the entire tome. This raises doubts about the possibility that the one identified as tome one could be the drafting of a further 'edition' and that tome three is the last copy of a broader coordinated draft.

A handwritten note on the second volume (the Tôme troisieme), signed by Gabriel Marcel, seems to confirm the hypothesis. In 1872, he specifies that unfortunately only the third volume of this collection seems to have survived.

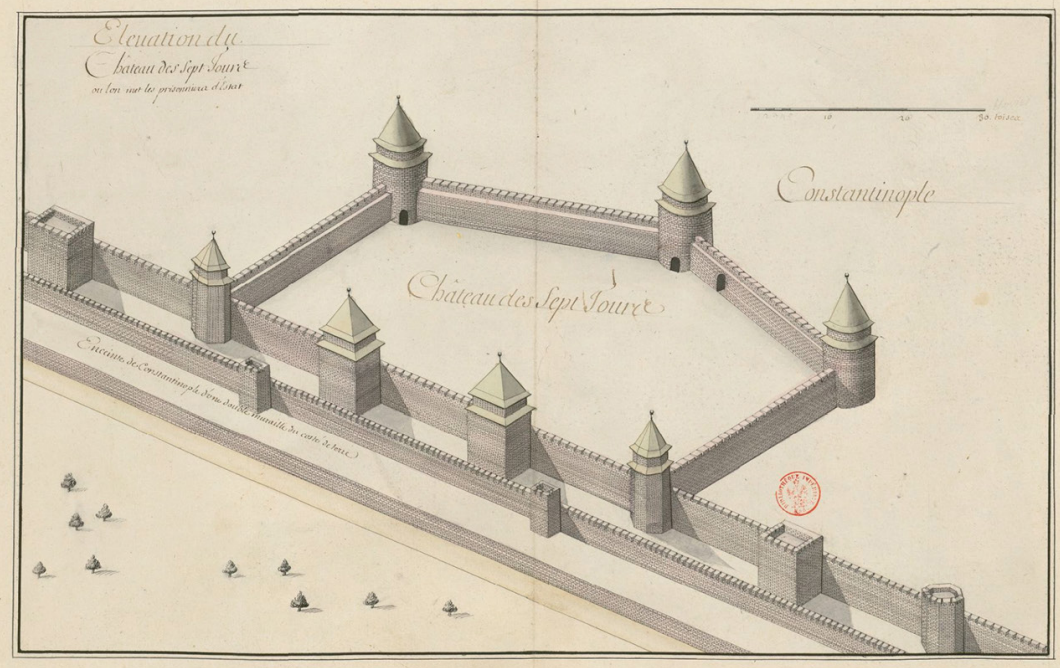


Given the list of places reviewed, and given the complementarity of the contents of the two manuscripts, it is possible to think that a third volume, containing the description of the ports of modern southern Turkey, has been lost.

The index of representations of the first manuscript shows 54 tables divided into the following sections: Costantinople, Andrinople, Smirne, Solonique, Athene, Candie. The six locations represent the map of the strategic ports for the control of the Aegean archipelago and the passage to the Black Sea.

The index of representations of the second manuscript shows $5 \mathrm{I}$ tables divided into the following sections: L'sle de Chipre, Syrie, Terre Saincte and L'Egipte. Especially, in this index 7 tables of the section dedicated to the southern part of the Holy Land are missing (tables 24-30).

The index shows only the numbering of the tables without the title and there are no associated tables.

Instead, were added in pencil by a second editor: table 19 bis, in the Holy Land section, and three other final tables (tables 49-5I) in the section dedicated to Egypt. In this case, we can hypothesize an archive reorganization that has somehow tried to reorganize the documentary collection.

The drawings allow observations to be made on the geometric knowledge adopted by the so-called capitaine de vaisseau, that is Étienne Gravier, Marquis of Ortières.

The collection includes nautical charts with some measurements; representations in plan and elevation of buildings of great architectural value; accurate parallel projections with a graphic reference scale (fig. I), and finally, scenographic perspectives (fig. 2) with a less rigorous realization than the one we use today with the Central Projection method. Among the most valuable drawings, we point out the panoramic views made with very accurate details. Having a particular interest in the port cities of the Holy Land [I], the panoramic view of Acco taken from the sea appeared particularly interesting (fig. 3).

A detailed study made it possible to trace, through the principles of perspective restitution, the existence of a precise point of view (figs. 4, 5).

The hypothesis seems to demonstrate an exact correspondence between the panoramic view of the city created by Gravier and the mapping of the known architectural emergencies. To do this, the following steps were performed.

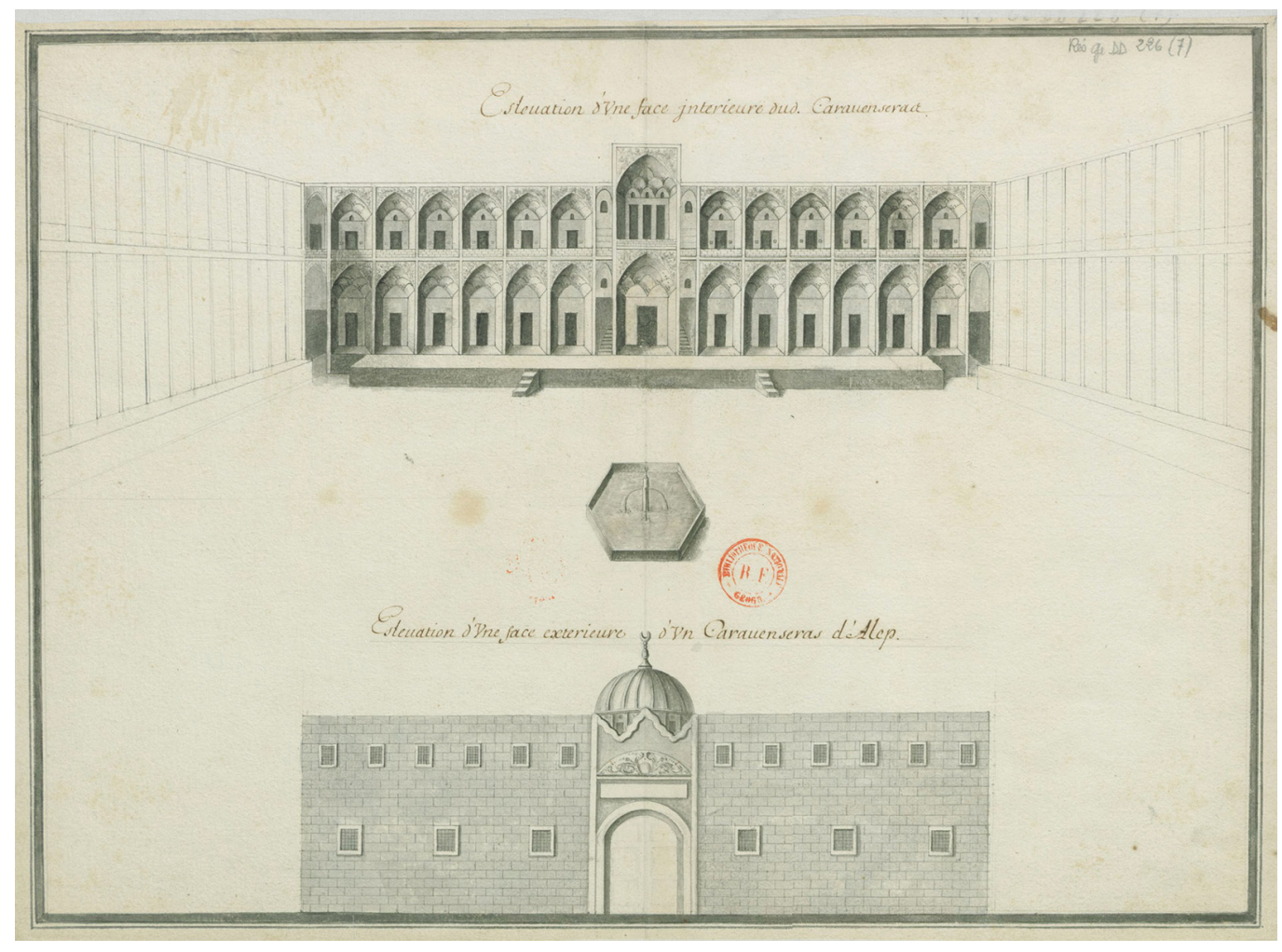


In the beginning, accurate recognition of the architectural emergencies represented by Gravier in the elevation was carried out, this operation was facilitated by some toponyms reported in correspondence with the main buildings. Two types of annotations can be observed, two marked in ink, relating to the Palais du grand maitre and the Eglise St. Jean, and one marked in pencil but with the same handwriting relating to the Eglise Saint André.

Unfortunately, the current evidence of the three monuments allows us to locate only the 'Grand Master's Palace' today identifiable with the citadel of the hospitals [Luschi, Aiello, 2020]. However, from a careful analysis of the representation, some architectures on the seafront seem to have a good match.

The viewpoint coincides with a view from the sea to the south of the city and offers many details of the conformation of the old port. The emergent ruins suggest the original extension. In the panorama, between the boats, it is possible to recognize a mosque near the port. The position seems to coincide with that of the current Sinan Basha. Looking to the right, on the coastline, you can see an imposing quadrangular tower identifiable with the current tower of the burj al-Sultan. Three arches could be those of the site of the former convent of the Poor Clares on which the current khan a-Shawarda stands. Going on, the overview extends for a long stretch to show the remains of many buildings in ruins. The geography of the place shows a second mountainous plane in the background which means that the observer is shifting the view towards the hinterland. In the foreground, on the right, a small hill is drawn near the coast. Observing the shape, this can be identified with Tell el-Fukhar the 'hill of clay vessels', an archaeological site located to the east of the current city.

Having established the main reference targets, and after having identified them on the modern plan of the city, the next step was to reconstruct a perspective system capable of recreating a one-to-one correspondence between the panoramic view of the city and the respective plan.

To carry out this operation, it supposes that the panorama had been constructed thanks to the use of the tools of a nautical chart editor, therefore with instruments capable of measuring the exact angles.

From a technical point of view, given the horizontal extension of the panorama, a curved frame of reference has been hypothesized, similar to a portion of cylindrical surfaces, which

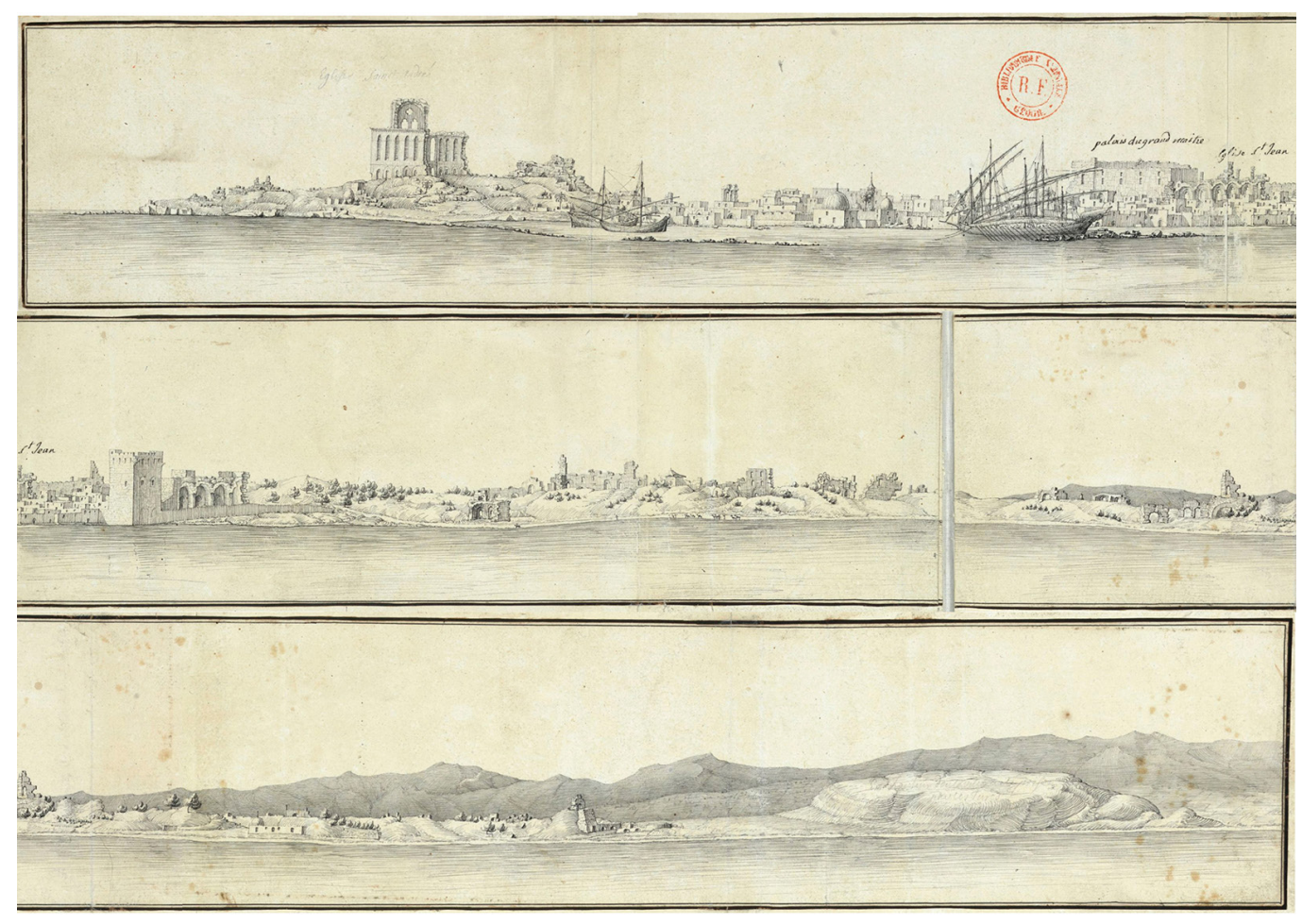


Fig. 4. Studies on the centre of perspective projection of the panorama of San Giovanni d'Acri realized by Gravier in 1687 (Aiello graphic rendering).

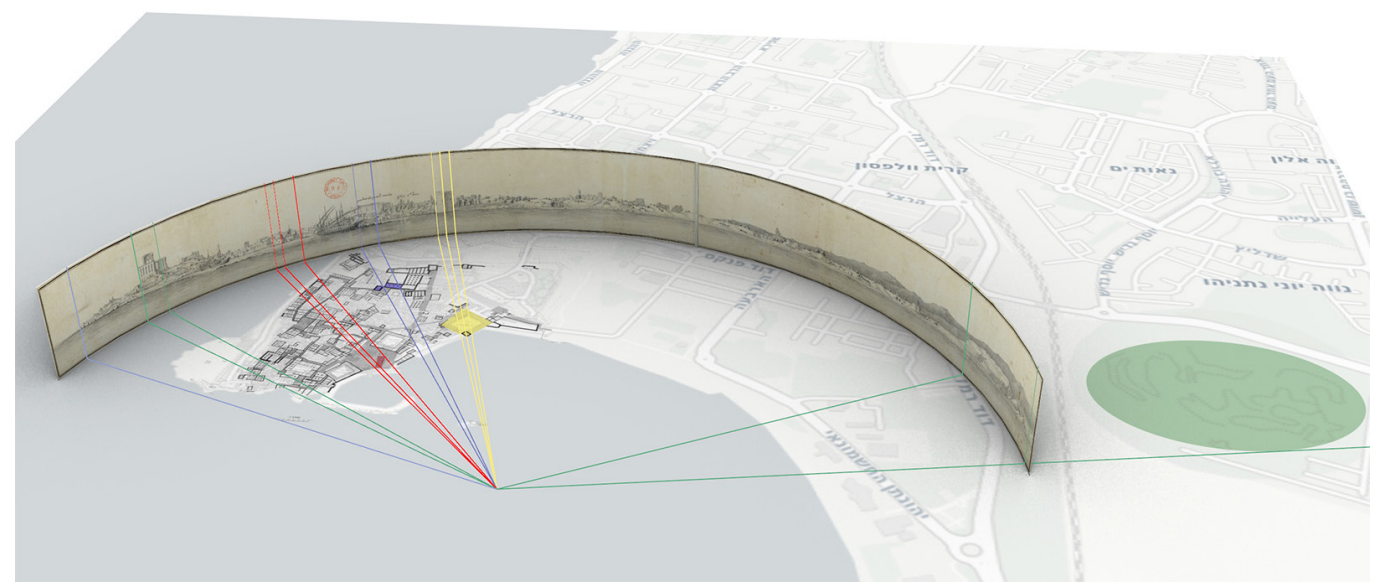

would allow not to incur the normal optical deformation that presupposes a projection from a specific point onto a flat frame.

It should be noted that this setting does not represent a geometric construction declared by the landscape painter (Gravier) but adopted by the writer to verify the resulting geometric obtained. In fact, for the design of panoramas and architectural emergencies, the use of technical instruments for the measurement of azimuth angles is assumed.

By setting the landscape painter's point of view on a boat anchored just outside the port of the city and assuming that he wants to represent the panorama faithfully, the draftsman could associate each azimuth angle/interval detected with a linear extension of the panorama and represent in proportionately all the elements between one interval and the next.

This practice, even if not expressly codified at the end of 1600, will be treated in scientific terms by Gaspard Monge (1746-8I8) in the treatise on descriptive geometry [Heather, $185 \mathrm{I}$ ]. Indeed, in the text it is possible to read: "Panoramas are perspectives drawn on vertical cylindrical surfaces, whose bases are circular, the point of view being taken on the axis of the cylinder. To place any point in perspective on the surface of a vertical cylinder, conceive a vertical plane, drawn through the eye and the proposed point, cutting the surface in a vertical line to be determined by the intersection of the

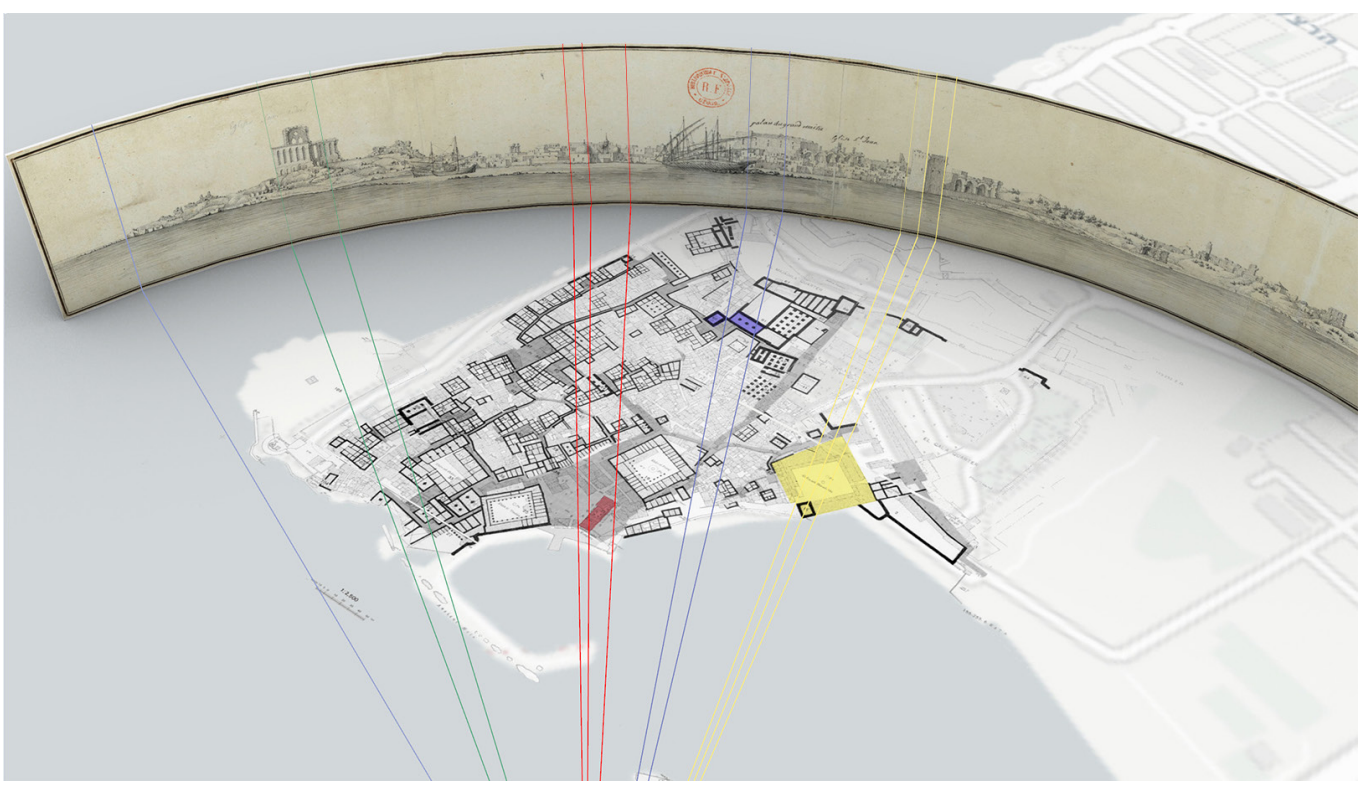




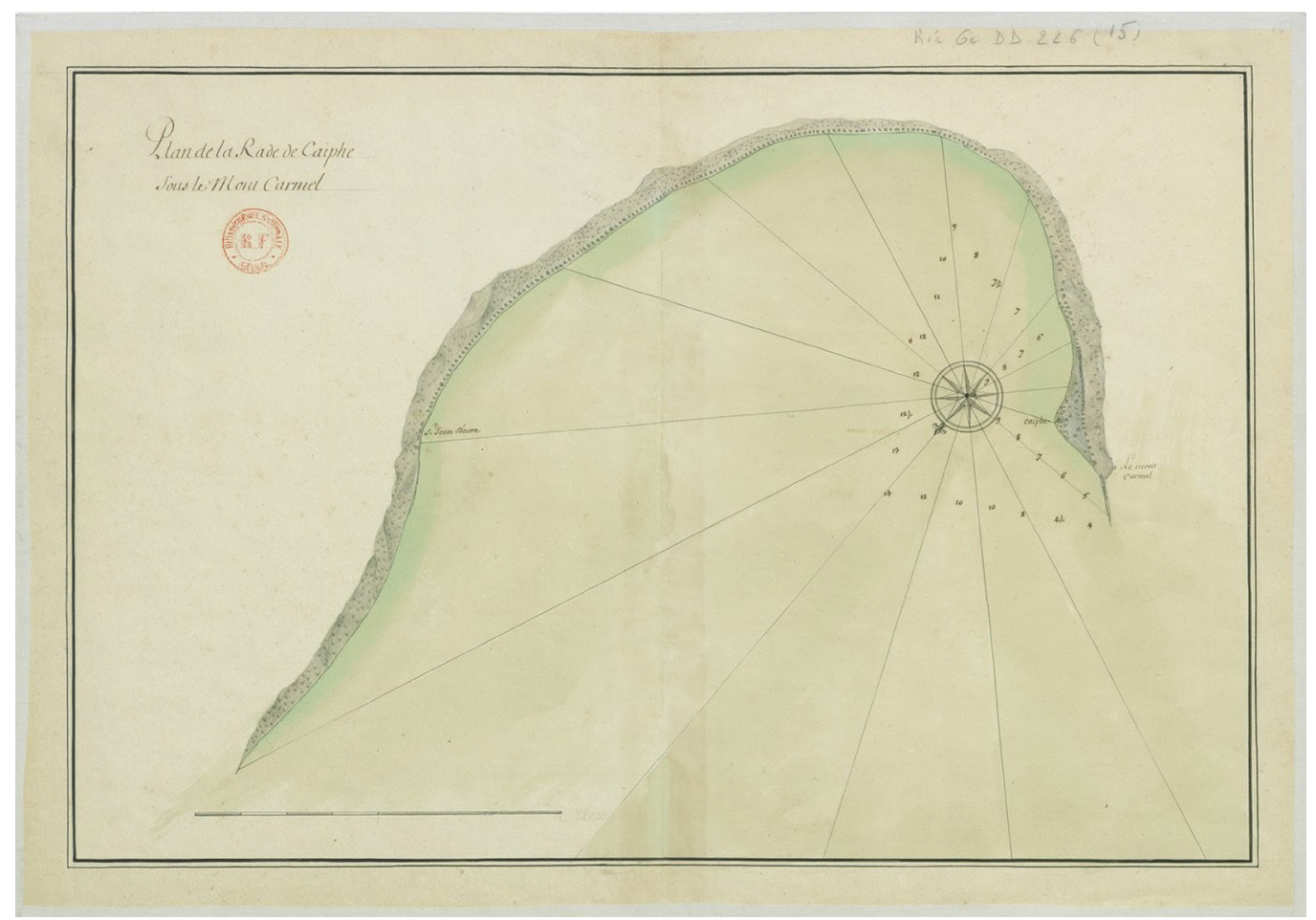

horizontal trace of the plane with the circumference of the circular base of the cylinder. Construct the vertical projection of this line, and its intersection with the vertical projection of the visual ray will determine the height, above the base of the cylinder, at which the visual ray meets its surface; and it will now be easy to construct the perspective of the proposed point, either on the surface of the cylinder itself or on its development" [Heather |85 I, p. III].

The Treaty, therefore, describes scientifically the exact procedures to be implemented in the representation of a panorama, recognizing the need to assume the use of a cylindrical surface.

In support of the theory, it is interesting to observe the nautical chart, drawn by Gravier himself (fig. 6), of the Gulf of Caiphe, Haifa.The map shows off the coast of Haifa a windrose with the respective azimuth rays that divide the map into sectors according to the cardinal points. The analysis of the document allows us to appreciate a graphic technique capable of mixing a plan view, given by the silhouette of the coastline, and the representation of a long panorama.

Indeed, looking closely at the representation, it is possible to appreciate that what seems, at first sight, the planimetric description of the coastal territories. In reality, the map shows a miniature of the whole landscape, offering a broader description of the hinterland as seen from the sea. In this way, paying attention to the city of Haifa it is possible to see the representation of Mount Carmel and the presence of some buildings on its top (fig. 7). Looking at the city of Acco, on the other hand, even in such a small miniature, you can see an imposing building on the northern edge of the city, probably identifiable with the grandiose ruins of Sant'Andrea (fig. 8).

The analyses presented, the recognition in the plan of the viewpoint of the landscape and the azimuthal association of the mainland markers, thus provide new information relating to the positioning of the main historical monuments lost to date and they open new research perspectives to support the archaeology site. In this context, we highlight how these studies converge towards current research relating to the controversial location of the historic site of the church of Sant'Andrea [Luschi 2018, pp. 27-38; Zerbini, Vezzi 20I 8; Taormina 2019, pp. 75-90]. 
Fig. 7. Plan de la Raide

[Gravier 1687b, Table 15]
Detail of Caiphe, Haifa.

Fig. 8. Plan de la Raide Caiphe', I 685-1687 Gravier I687b, Table I5] Detail of St. Jean D'Acre
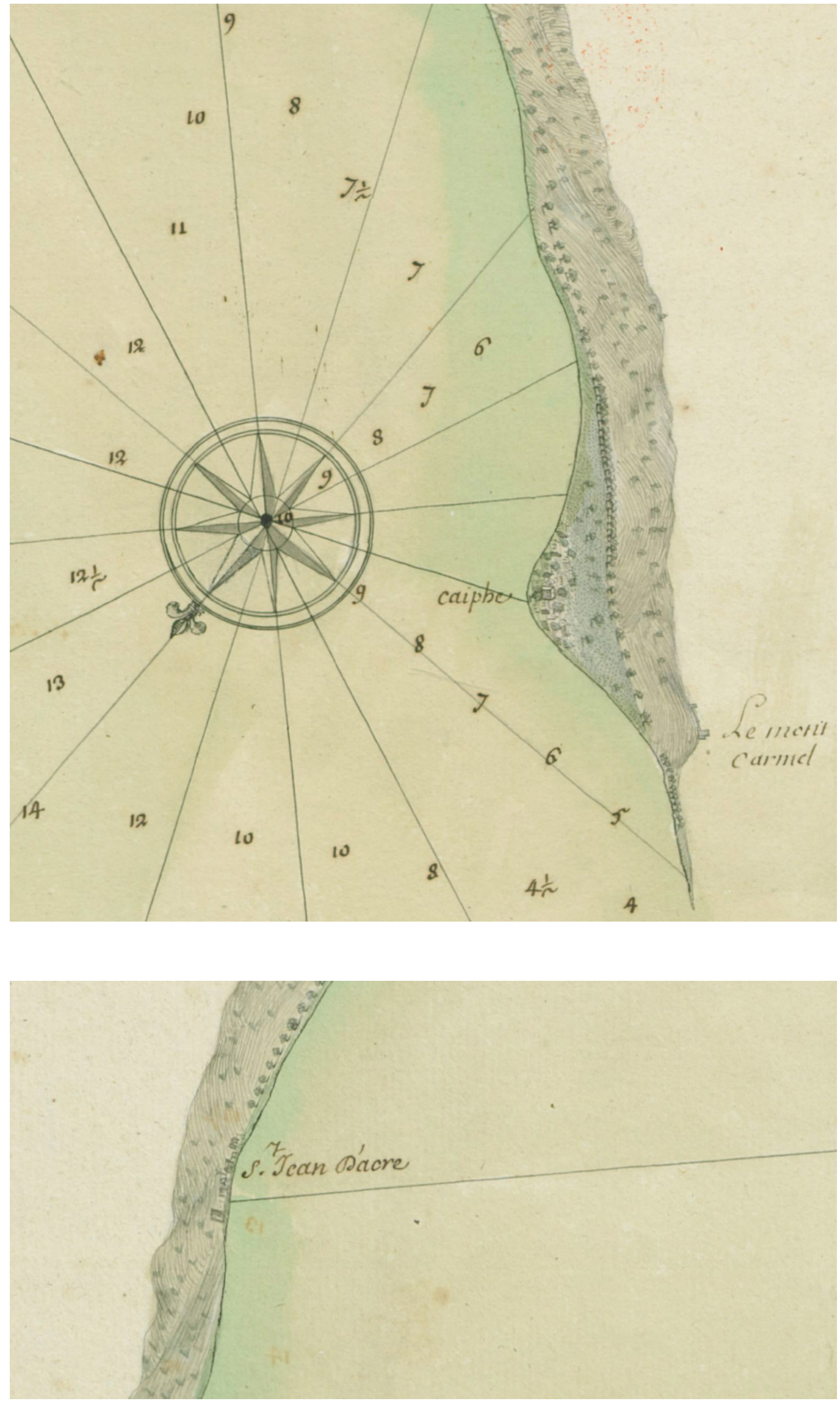
Fig. 9. Geometric studies on perspective constructions, p. 5].

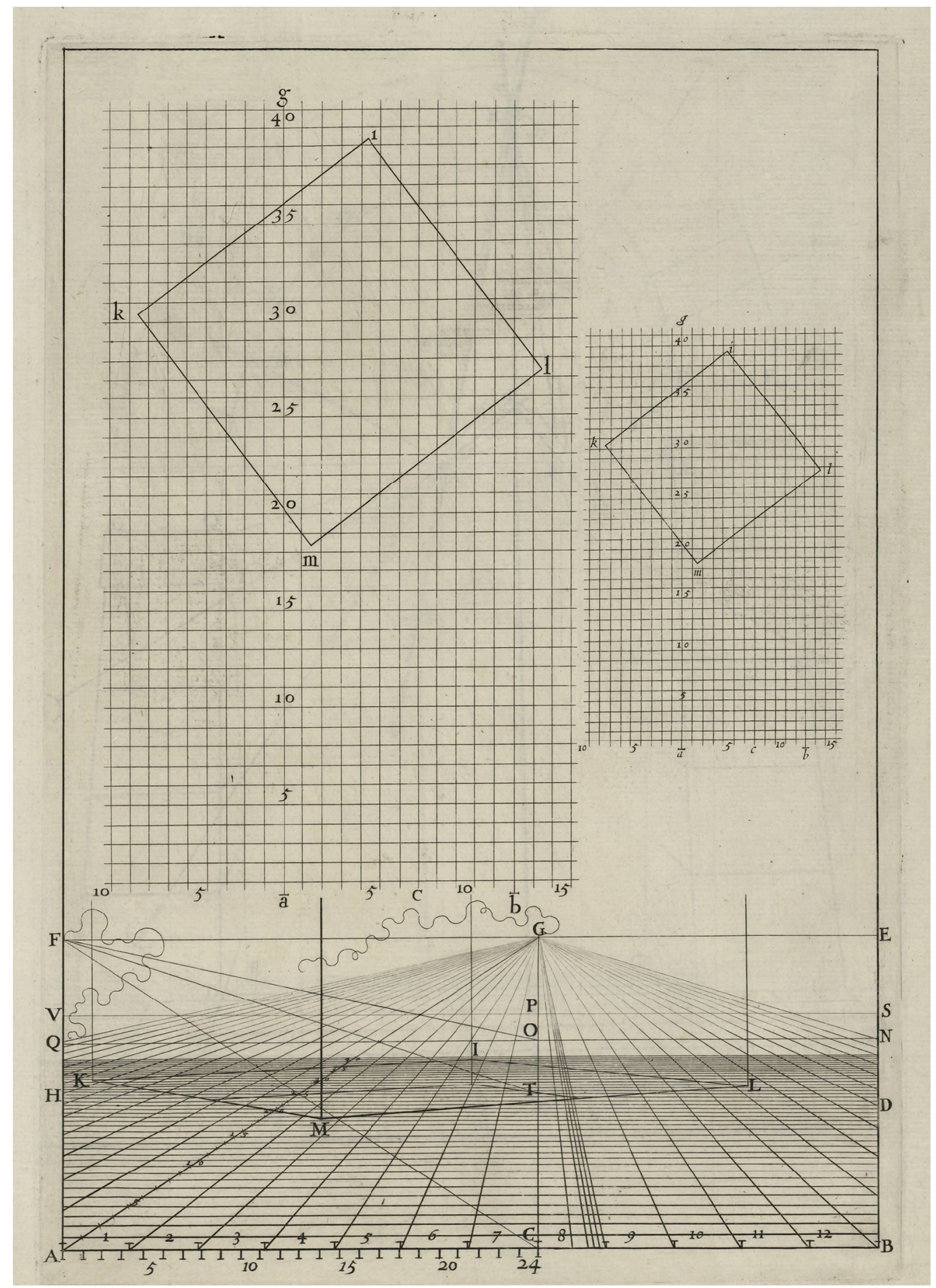

\section{Conclusions}

We can say that the analysis of the graphic representations of Monsieur Gravier highlight an important element in the study of the evolution of seventeenth-century representation techniques especially in the geographical field and in the representation of landscapes in which it seems to excel.

The reconstruction of the perspective systems allows important information on the exact geographical location of the monuments lost in the last four centuries. If we coordinate this 
information with the study of individual monuments, we can finally obtain important news for archaeological research.

Standing in the technical field, the perspective adopted by Gravier for the representation of the buildings uses a scenographic system, therefore with several vanishing points. So he uses a method useful for viewing the object but different from the rules of the central perspective. Looking at the theoretical landscape of the time, we can say that the practice does not exactly follow the theoretical approach of contemporary treatise writers. We recall how the architect Girard Desargues (159 - - 66 I) in his short treatise on cutting stones [Desargues 1640] had already discussed the "perspective of a figure and the placement of its geometric planes" [Aterini 2009, p. 39].

Nevertheless, we could argue that it is not always necessary for a specialist to know/use all the sciences of representation so that Gravier appears less interesting for small-scale detailed drawings but of great interest for large-scale representations. The study reveals the opportunity to offer an important documentary source to be studied for the knowledge of the historical sites of the eastern Mediterranean.

\section{Notes}

[I] These studies were born and developed within the Italian-Israeli Askgate program with recognition of the Ministry of Foreign Affairs and International Cooperation.

\section{References}

Aterini B. (2009). Introduzione ai metodi della rappresentazione della Geometria Descrittiva. Firenze: Alinea.

Corridi F. (Ed.) (1838). Trattato di Geometria descrittiva di G. Monge. Con l'aggiunta d'una teorica delle ombre e della Prospettiva estratta dalle lezioni inedite dell'autore per cura del signor Brisson. Firenze.

Desargues G. ( 640). Maniere universelle de S.G.D.L. touchant la pratique du trait à preudes pour la coupe des pierres an l'Architecture. Parigi.

Gravier É. (1687a). Estat des places que les princes mahométans possèdent sur les costes de la mer Méditerranée et dont les plans ont esté levez par ordre du Roy a la faveur de la visitte des Eschelles du Levant, que Sa Majesté a fait faire les années 1685 , 1686 et 1687 avec les proiets pour y faire descente et s'en rendre maistres. Tome I [Levés d'ordre du sieur Gravier d'Ortière commandant le vaisseau de Sa Majesté le Jason].

Gravier É. (1687b). Estat des places que les princes mahométans possèdent sur les costes de la mer Méditerranée et dont les plans ont esté levez par ordre du Roy a la faveur de la visitte des Eschelles du Levant, que Sa Majesté a fait faire les années I 685 , I 686 et 1687 avec les proiets pour y faire descente et s'en rendre maistres. Tome Troisième [Levés d'ordre du sieur Gravier d'Ortière commandant le vaisseau de Sa Majesté le Jason].

Heather J.F. (Ed.) (I85 I). An Elementary treatise on Descriptive Geometry, whit a Theory of shadows and of perspective: extracted from the French of G. Monge. London: John Weale, 59, High Holborn.

Luschi C., Aiello L. (2020). La ricostruzione storica della città attraverso l'iconografia urbana. II caso studio di San Giovanni d'Acri. In Arena A., et al. (a cura di). Connettere. Un disegno per annodare e tessere. Atti del $42^{\circ}$ Convegno Internazionale dei Docenti delle Discipline della Rappresentazione/Connecting. Drawing for weaving relationships. Proceedings of the 42 th International Conference of Representation Disciplines Teachers, pp. 2369-2382. Milano: FrancoAngeli.

Luschi C.M.R. (2018). Among the archaeologists and the designers: a critical survey of Sant'Andrea of Acre in Israel - Wśród archeologów i projektantów: krytyczna ankieta kościoła Sant'Andrea Akko w Izraelu. In Czasopismo Techniczne, vol. I I.

Migliari R. (2009). Geometria descrittiva. Voll. I e II. Torino: CittàStudi Edizioni.

Taormina F. (2019) Akko e la sostenibilità morfologica della città antica. Saggio sulla vita delle forme. Palermo: 40due edizioni.

Zerbini M.,Vezzi A. (20 I 8). II nuovo orizzonte del porto crociato di San Giovanni d'Acri. In Benincasa F. (Ed.). Seventh International Symposium: monitoring of Mediterranean Coastal Areas: Problems and Measurement Techniques. Livorno (Italy), June 19-20- 21, 2018, pp. 213-221. Firenze: Firenze University Press.

\section{Author}

Laura Aiello, Università degli Studi di Firenze, laura.aiello@unifi.it

To cite this chapter. Aiello Laura (2021). I disegni di viaggio di Étienne Gravier. Restituzioni prospettiche e ipotesi ricostruttive/Travel Drawings by Étienne Gravier. Perspective Restitution and Reconstructive Hypotheses. In Arena A., Arena M., Mediati D., Raffa P. (a cura di). Connettere. Un disegno per annodare e tessere. Linguaggi Distanze Tecnologie. Atti del $42^{\circ}$ Convegno Internazionale dei Docenti delle Discipline della Rappresentazione/ Connecting. Drawing for weaving relationship. Languages Distances Technologies. Proceedings of the 42th International Conference of Representation Connecting. Drawing for weaving relationship. Languages Dista
Disciplines Teachers. Milano: FrancoAngeli, pp. 1884-1901. 